DOI: https://doi.org/10.24127/ajpm.v8i2.2156

\title{
PENGEMBANGAN SMART BOOK MATERI GEOMETRI UNTUK SISWA SMP BERBASIS KONSTRUKTIVISME
}

\author{
Dian Fitri Argarini ${ }^{1}$, Nok Izatul Yazidah ${ }^{2}$, Anik Kurniawati ${ }^{3}$ \\ 1,2,3 Pendidikan Matematika, IKIP Budi Utomo Malang \\ E-mail: $\quad$ kejora.subuh14@gmail.com ${ }^{1)}$ \\ izatulyazidah@gmail.com ${ }^{2)}$ \\ anikkurnia2016@gmail.com $^{3)}$
}

Received 31 July 2019; Received in revised form 1 November 2019; Accepted 6 November 2019

\begin{abstract}
Abstrak
Penelitian ini dilatarbelakangi oleh masalah yang ada disekolah yang terkait dengan materi geometri dan bahan ajar yang membuat siswa kurang konstruktif dalam pemahamannya. Penelitian ini bertujuan untuk menghasilkan SMART book materi geometri untuk siswa SMP berbasis konstruktivisme yang valid, praktis dan efektif. Penelitian ini adalah penelitian pengembangan yang diadaptasi dari model pengembangan Plom yang terdiri dari 3 tahap, yaitu tahap Preliminary Research, tahap Prototype Stage, dan terakhir adalah tahap Assessment Phase. Kevalidan produk ini dilihat dari hasil validasi ahli, kepraktisan produk dilihat dari hasil lembar angket yang telah diisi oleh subjek, sedangkan keefektifan produk dilihat dari hasil uji coba SMART Book. Hasil uji coba ini menghasilkan nilai rata-rata siswa adalah 80,05 yang telah memenuhi kriteria sangan baik dari standar kelulusan minimum yang ditentukan oleh sekolah adalah 75 untuk mata pelajaran matematika.
\end{abstract}

Kata Kunci: konstruktivisme; geometri; SMART book.

\begin{abstract}
This research is motivated by the problems that exist in schools related to geometry material and teaching materials that make students less constructive of their understanding. This study aims to produce SMART Book geometry material for constructivism-based junior high school students who are valid, practical and effective. This research is a development research adapted from the Plomp model which consists of 3 stages, namely Preliminary Research, Prototype Stage, Assessment Phase. The validity of the product is seen from the results of expert validation. The practicality of the product is seen from the results of the questionnaire that has been filled in by the subject. Effectiveness seen from the results of the SMART book trial. The results of this trial produce the average value of students is 80.05 which has met the criteria very well from the minimum graduation standard determined by the school is 75 for mathematics subjects
\end{abstract}

Keywords: constructivism; geometry; SMART book

\section{PENDAHULUAN}

Geomeri merupakan salah satu cabang ilmu matematika yang sangat terkait dengan bentuk, ukuran dan letak, Geometri juga merupakan salah satu cakupan bidang dalam matematika yang mempunyai peran penting dalam kehidupan sehari-hari. Dari mulai jenjang sekolah dasar sampai dengan perguruan tinggi selalu ada materi geometri dalam matematika. Menurut Safrina, dkk (2014) menyatakan bahwa geometri dapat dikatakan sebagai salah satu materi yang diamggap penting dalam matematika.

Terdapat terdapat banyak konsep matematika yang diwakili dengan geometri, hal inilah yang menyebabkan pentingnya konsep 
geometri untuk dijadikan alat penting untuk menyelesaikan masalah (Marlina, 2013). (Nopriana, 2015) menyatakan bahwa geometri adalah bagian dari bidang studi matematika yang penting untuk dipelajarai, tidak hanya bisa membina proses berfikir siswa, geometri juga sangat mendukung topiktopik lain di dalam matematika. Dari pemaparan itu semua maka dapat disimpulkan betapa pentingnya geometri untuk dipelajari bagi siswa.

Dalam mempelajari geometri siswa akan melewati tingkat berfikir yang bertingkat-tingkat. Bagi siswa Sekolah Menengah Pertama (SMP) berdasarkan hasil penelitian Muhassanah, dkk (2014) yang menyatakan bahwa tingkat berfikir siswa SMP dalam belajar geometri tertinggi pada tingkat 2 yaitu deduksi informal dan sebagian besar siswa berada pada tingkat 0 yaitu visualisasi. Padahal bila merujuk pada teori perkembangan piaget bahwa siswa SMP harusnya berada pada tingkat berfikir ideal pada tahap formal. Ini mengakibatkan bahwa siswa-siswa yang hidup pada tahap visualisasi meraka mengalami kesulitan. Ini mengakibatkan geometri selalu menjadi hal yang menakutkan dan sulit difahami oleh siswa.

Beberapa penelitian yang relevan menunjukkan bahwa pembelajaran dengan pendekatan konstruktivisme terbukti efektif dalam meningkatkan hasil belajar matematika, diantaranya adalah: Setiyawan (2016) yang menunjukkan bahwa bahan ajar yang berbasis konstruktivisme dapat meningkatkan kemampuan berfikir kristis siswa dan meningkatkan prestasi belajar. Rangkuti (2014) menyatakan dalam penelitiannya bahwa pembelajaran yang mengacu kepada teori belajar konstruktivisme lebih memfokuskan pada kesuksesan siswa dalam mengorganisasikan pengalaman mereka. Melalui pembelajaran konstruktivisme, siswa ditempa sehingga memahami teori dan latihan serta dapat mengaplikasikannya dalam soal yang berbeda dan dalam kehidupan nyata.

Namun kenyataannya sekarang, berdasarkan hasil wawancara dengan guru yang menyatakan bahwa, materi yang paling susah adalah geometri dengan bobot kesulitannya tinggi. Karena materi geometri itu jika dibuat soal masih bisa terus dikembangkan lebih tinggi tingkat kesulitannya, serta dalam materi geometri ini siswa dituntut untuk berimajinasi (membayangkan) gambargambarnya dan dituntut memiliki tingkat logika yang tinggi. Sebagai contoh teorema Phytagoras awalnya hanya rumus simpel, namun ketika soal Ujian Nasional (UN) ada lagi pengembangan soal yang lebih dalam lagi sehingga siswa butuh analisis dan kesulitan. Lebih lanjut guru mengatakan bahwa ada tiga faktor yang mempengaruhi materi geometri itu susah di fahami dan dipelajari antara lain yaitu (1) guru yang kurang menguasai materi dan kurang kreatif dalam mengajar; (2) minat belajar siswa kurang, dan yang terakhir (3) bahan ajar kurang menarik.

Bahan Ajar memegang peranan yang sangat penting dalam pembelajaran matematika. Khotimah,dkk (2012) menyatakan bahwa dalam rangka meningkatkan kemampuan siswa untuk memahami konsep pembelajaran selain model pembelajaran yang digunakan, seorang guru juga dituntut menggunakan sumber belajar yang dapat mempercepat proses pemahaman konsep tersebut. Sumber belajar salah satunya adalah bahan ajar. 
Namun sekarang sering kali buku ajar yang ada disekolah kadang hanya bersifat penyampaian materi saja dan yang menjadi pusat dalam proses belajar mengajar adalah guru. Sehingga buku yang telah ada hanya sebagai alat bantu saja dalam penyampaian materi, siswa hanya membaca dan mendengarkan penjelasan guru saja. Untuk mengatasi masalah-masalah di atas, serta untuk memvisualisakan dan memahami konsep geometri pada siswa maka diperlukan suatu buku ajar yang dapat membuat siswa menjadi aktif dalam kegiatan belajar mengajar di kelas, buku ajar yang dapat mengkontruk pemahaman siswa. Prinsip-prinsip dalam pendekatan konstruktivisme diantaranya adalah (1) pengetahuan dibangun oleh siswa sendiri, baik secara individual maupun sosial; (2) pengetahuan tidak dapat dipindahkan dari guru ke murid, kecuali hanya dengan keaktifan murid sendiri untuk menalar, (3) murid aktif mengkonstruk terus menerus, sehingga selalu terjadi perubahan konsep perubahan konsep menuju ke konsep yang lebih rinci, lengkap, serta lengkap dengan konsep ilmiah; (4) guru hanya sekedar membantu menyediakan sarana dan situasi agar proses konstruk siswa berjalan mulus (Nurhidayati, 2017) . Sesuai dengan prinsip dari pembelajaran konstruktivisme yang ada pada point 2 maka materi dalam matematika yang cocok untuk bernalar adalah materi Geometri. Karena dalam materi geometri banyak memuat gambargambar yang membutuhkan penalaran.

Berdasarkan uraian tentang fakta permasalahan di atas, maka tujuan penelitian ini adalah untuk mendeskripsikan dan menghasilkan sebuah produk berupa SMART book yang berbasis konstruktivisme yang valid, praktis, dan efektif. Buku ajar yang digunakan dalam penelitian ini disebut dengan SMART book. Dimana setiap huruf dalam kata "SMART" memiliki kepanjangan dan makna tersendiri seperti huruf $\mathrm{S}$ dalam kata SMART mewakili prinsip "spesifik". Spesifik memiliki arti khusus atau khas, khusus disini adalah materi yang diangkat adalah khusus untuk materi geometri. M mewakili kata mudah, diharapkan dalam penggunaannya akan lebih memudahkan siswa dan guru. A mewakili kata aktif, karena dalam penggunaanya akan merangsang siswa untuk lebih aktif dalam pembelajaran. $\mathrm{R}$ berarti realistik yang menandakan bahwa permasalahan atau ilustrasi dalam buku ini seputar masalah seharihari yang terjadi di sekitar lingkungan siswa. Sedangkah huruf $\mathrm{T}$ mewakili kata tepat, tepat berarti prosedur penyelesaian yang ditawarkan dalam $S M A R T$ Book adalah penyelesaian yang tepat.

\section{METODE PENELITIAN}

Jenis penelitian ini adalah penelitian pengembangan (research dan development). Penelitian dan pengembangan SMART Book berbasis konstruktivism ini menggunakan model pengembangan Plomp (2010) yang terdiri atas tiga tahap, yaitu (1) penelitian awal (Preliminary Research), bertujuan untuk melakukan observasi awal tentang hal-hal yang berkaitan dengan pengembangan SMART Book berbasis konstruktivis, (2) perancangan protipe (Prototyping Stage), yaitu dengan mengembangkan pengembangan SMART Book berbasis konstruktivisme serta melakukan evaluasi formatif, dan (3) tahap penilaian (Assessment Phase), yaitu dengan melakukan evaluasi sumatif atau semi sumatif, memberikan kesimpulan apakah SMART Book berbasis 
konstruktivisme dapat memecahkan masalah sesuai yang diharapkan, serta melakukan revisi SMART Book berbasis konstruktivism berdasarkan kesimpulan dan masukan sehingga dihasikan SMART Book berbasis konstruktivism (Modul Hasil Pengembangan). Bagan aktivitas pengembangan dalam penelitian disajikan pada Gambar 1.

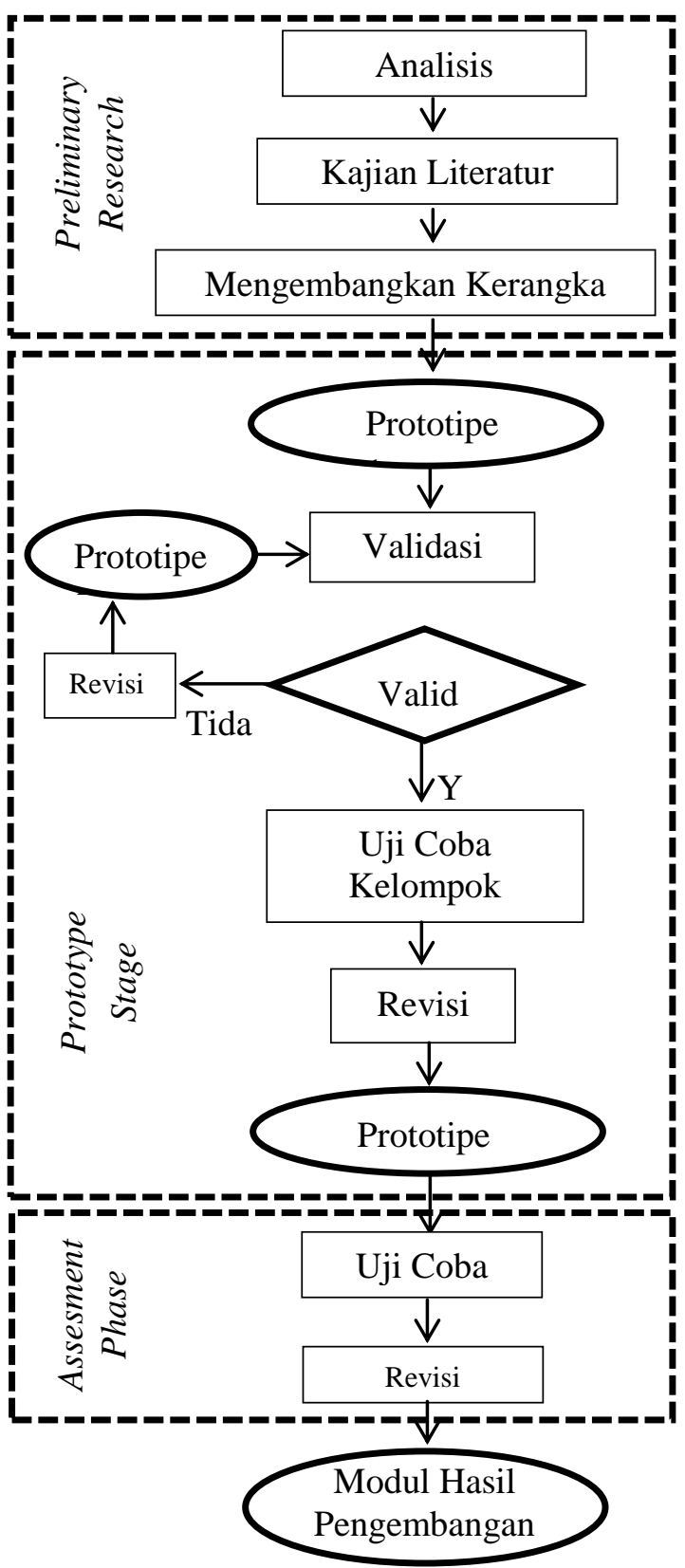

Gambar 1. Tahap-tahap Pengembangan SMART book
Prototype yang dikembangkan melalui studi pendahuluan diuji validitasnya oleh dosen IKIP Budi Utomo Malang sebagai pakar atau ahli bahan ajar. Data validasi terdiri atas data kuantitatif. Data kuantitatif merupakan skor-skor yang diperoleh dari validator dengan menggunakan skala yang mencakup aspek kepraktisan dan keefektifan SMART Book. Sementara itu, data kualitatif, berupa saran, komentar, dan kritik baik secara tertulis maupun lisan. Data validasi baik kuantitatif maupun kualitatif digunakan sebagai bahan pertimbangan untuk melakukan revisi demi penyempurnaan SMART Book (prototype 2). Selain itu, untuk mendapatkan hasil pengembangan yang maksimal, maka dilakukan penilaian terlebih dahulu, adapun penilaian tersebut didapatkan dari hasil wawancara.

Instrumen yang digunakan dalam penelitian ini adalah (1) lembar Validasi ahli ; (2) angket respon siswa; (3) Lembar tes. ketiga instrumen tersebut digunakan untuk mengetahui ke validan, kepraktisan dan keefektifan dari SMART Book ini.

Uji kevalidan menggunakan lembar validasi, sedangkan data yang diamati adalah kevalidan SMART Book, lembar tes, lembar observasi dan angket yang diisi oleh masing-masing 1 orang ahli materi, 1 orang ahli media dan satu orang ahli bahasa. Uji kepraktisan menggunakan lembar angket, data yang diisi oleh 15 siswa kelas VII di SMP Tarbiyyatus Shibyan Tajinan Malang. Uji keefektifan menggunakan nilai dari hasil tes setelah menggunakan SMART Book ini.

Teknis analisis data hasil uji kevalidan yang dilakukan dengan tiga langkah yaitu (1) melakukan rekapitulasi data penilaian SMART Book untuk masing-masing validator; (2) 
DOI: https://doi.org/10.24127/ajpm.v8i2.2156

menentukan rata-rata nilai hasil penilaian dari masing-masing validator;(3) Menentukan skor validasi $\left(V_{a}\right)$. Selanjutnya hasil yang diperoleh akan dibandingkan dengan kriteria kevalidan perangkat pembelajaran seperti pada Tabel 1.

Tabel 1. Kriteria Penilaian Hasil

\begin{tabular}{|c|c|c|}
\hline \multicolumn{3}{|c|}{ Validasi } \\
\hline Interval & $\begin{array}{l}\text { Kriteria } \\
\text { Kevalidan }\end{array}$ & Keterangan \\
\hline $\mathbf{1} \leq V_{a}<2$ & $\begin{array}{l}\text { Tidak } \\
\text { Valid }\end{array}$ & $\begin{array}{l}\text { SMART } \\
\text { Book tidak } \\
\text { bisa di } \\
\text { gunakan }\end{array}$ \\
\hline $\mathbf{2} \leq \boldsymbol{V}_{a}<\mathbf{3}$ & $\begin{array}{l}\text { Kurang } \\
\text { Valid }\end{array}$ & $\begin{array}{l}S M A R T \\
\text { Book bisa } \\
\text { di gunakan } \\
\text { dengan } \\
\text { revisi }\end{array}$ \\
\hline $3 \leq V_{a}<4$ & $\begin{array}{l}\text { Cukup } \\
\text { Valid }\end{array}$ & $\begin{array}{l}\text { SMART } \\
\text { Book bisa } \\
\text { di gunakan } \\
\text { dengan } \\
\text { revisi }\end{array}$ \\
\hline $3 \leq V_{a}<4$ & Valid & $\begin{array}{l}\text { SMART } \\
\text { Book bisa } \\
\text { di gunakan } \\
\text { tanpa revisi }\end{array}$ \\
\hline $4 \leq V_{a} \leq 5$ & $\begin{array}{l}\text { Sangat } \\
\text { Valid }\end{array}$ & $\begin{array}{l}\text { SMART } \\
\text { Book bisa } \\
\text { di gunakan } \\
\text { tanpa revisi }\end{array}$ \\
\hline
\end{tabular}

Teknik analisis data hasil uji kepraktisan dilakukan dengan langkahlangkah berikut (1) melakukan rekapitulasi data penilaian angket respon siswa yang telah diisi oleh responden; (2) menghitung rata-rata nilai hasil dari semua yang diberikan responden; (3) menghitung total keseluruhan nilai rata-rata kepraktisan $(P)$ dari semua penilaian yang diberika responden. Selanjutnya hasil yang diperoleh akan dibandingkan dengan kriteri kepraktisan SMART Book seperti pada Tabel 2.
Tabel 2. Kriteria penilaian hasil kepraktisan

\begin{tabular}{cll}
\hline Interval & $\begin{array}{l}\text { Kriteria } \\
\text { Kepraktisan }\end{array}$ & Keterangan \\
\hline $\mathbf{1} \leq \boldsymbol{P}<\mathbf{2}$ & Tidak Praktis & $\begin{array}{l}\text { Revisi } \\
\text { Total }\end{array}$ \\
$\mathbf{2} \leq \boldsymbol{P}<\mathbf{3}$ & Kurang Praktis & $\begin{array}{l}\text { Revisi } \\
\text { Sebagian }\end{array}$ \\
$\mathbf{3} \leq \boldsymbol{P}<\mathbf{4}$ & Praktis & $\begin{array}{l}\text { Tidak } \\
\text { Revisi }\end{array}$ \\
$\boldsymbol{P}=\mathbf{4}$ & Sangat praktis & Tidak revisi \\
\hline \multicolumn{2}{r}{ Sedangkan teknik analisis data }
\end{tabular}
untuk uji keefektifan dilakukan dengan menghitung persentase jumlah perolehan skor dari tes setelah dilakukan pembelajaran dengan menggunakan SMART Book ini. Persentase agar SMART Book ini dikatakan efektif adalah $80 \%$ siswa mendapatkan nilai rata-rata 75 dari nilai KKM yang telah ditentukan oleh pihak sekolah.

\section{HASIL PENELITIAN DAN PEMBAHASAN}

Deskripsi pengembangan SMART book materi geometri untuk siswa SMP melalui tahap Plomp dijabarkan sebagai berikut

\section{Preliminary Research}

Pada tahap preliminary research ini kegiatannya adalah menganalisis masalah yang ada di sekolah berkaitan dengan belajar pembelajaran matematika di kelas. Kegiatan selanjutnya adalah melakukan observasi dan wawancara terhadap guru pengampu mata pelajaran matematika.

Dari hasil observasi dan wawancara diperoleh hasil bahwa guru masih aktif dalam pembelajaran sedangkan siswanya pasif, ini dikarenakan buku yang digunakan dalam pembelajaran kurang menarik, dan cenderung membuat guru yang lebih aktif dalam pembelajaran. Buku 
DOI: https://doi.org/10.24127/ajpm.v8i2.2156

ajar yang digunakan dalam pembelajaran di kelas masih kurang membuat siswa tertarik untuk mempelajarinya. Contoh soal-contoh soalnya masih contoh soal yang sederhana kurang ada tantangan bagi siswa dalam penyelesaiannya. Sehingga pelu adanya inovasi baru dalam buku ajar yang ada di kelas.

$$
\text { Lebih lanjut, guru }
$$

mengungkapkan bahwa pada mata pelajaran matematika di SMP tersebut materi yang paling susah adalah materi geometri, dimana siswa dituntut mempunyai tingkat imajinasi dan visualisasi yang tinggi, siswa juga harus mempunyai tingkat logika yang cukup juga. Dalam pengembangan soal-soal geometri masih bisa dikembangkan ke dalam soal yang lebih sulit lagi.

Berdasarkan hasil analisis masalah tersebut lalu dilakukan analisis kebutuhan agar bisa membuat sebuah buku ajar yang menarik bagi siswa dan mudah memahamkan siswa dalam mempelajari materi geometri serta membuat siswa menggunakan pengetahuan yang sudah mereka punya ke dalam pengetahuan barunya. Selanjutnya peneliti mencari informasi tentang materi geometri yang ada di sekolah tingkat pertama.

Kegiatan yang dilakukan
selanjutnya adalah
pengklasifikasian materi geometri yang ada di SMP dan diperoleh hasil materinya adalah (1) Garis dan sudut, (2) segiempat dan segitiga, (3) Persamaan garis lurus, (4) teorema pythagoras, (5) lingkaran, (6) bangun ruang sisi datar, (7) transformasi, (8) kesebangunan dan kekongruenan. Serta membuat instrumen yang diperlukan untuk penelitian ini seperti: (1) lembar validasi untuk ahli materi, ahli media serta untuk ahli bahasa; (2) lembar Observasi; (3) angket untuk siswa; (4) lembar tes;. Pada pengembangan SMART book ini dengan mengkombinasikan dengan aspek-aspek konstrukvisme sehingga SMART Book ini tidak lagi membosankan bagi siswa, namun diharapkan dengan SMART Book ini bisa menkonstrukkan pemahaman siswa sehingga pembelajaran bisa lebih bermakna dan tidak membosankan.

\section{Prototype Stage}

Pada tahap prototype stage yang pertama ini setelah menganalisis dan mengklasifikasikan materi geometri, kegiatan selanjutnya adalah mendesain SMART Book yang berbasis konstruktivisme sedemikian rupa sehingga nantinya berbeda dengan buku geometri yang lainnya yang digunakan untuk tingkat sekolah menengah pertama ini. SMART Book ini berisi (a) halaman judul SMART Book; (b) Apersepsi (berisi tentang kaitan materi yang akan dipelajari dengan kehidupan sehari-hari; (c) peta konsep (berisi tentang urutan materi yang akan dipelajari); (d) "mari membaca" tujuannya adalah agar siswa mampu memahami dan memperoleh konsep materi yang dipelajari; (e) "mari Diskusi" dalam bagian ini yang ditampilkan adalah masalah yang nantinya akan digunakan untuk berdiskusi dengan teman sejawat siswa, dalam bagian ini juga akan digunakan untuk mengkonstruksi pengetahuan lama siswa ke dalam pengetahuan barunya; (f) "mari mencoba" pada bagian ini siswa diberikan soal untuk dikerjakan secara individual;(g) "evaluasi diri" (ini meruapakan bagian akhir dari setiap bab yang ada di SMART book.

Selanjutnya kegiatan yang dilakukan adalah Validasi ahli, Uji coba kelompok terbatas. Pada tahap kedua prototype stage ini peneliti melakukan validasi SMART Book materi 
geometri kepada (1) ahli materi dengan tujuan untuk mengetahui kedalaman materi geometri untuk tingkat SMP serta untuk mengetahui keakuratan, kemutakhiran dan konstruktivisme dari penyajian materi geometri yang ada di SMART Book ini; (2) ahli media bertujuan untuk mengetahui apakah ukuran SMART Book sudah sesuai dengan ISO, desain ampul SMART Book akan membuat siswa tertarik atau tidak; (3) ahli bahasa yang bertujuan untuk mengetahui apakah bahasa yang digunakan dalam SMART Book tidak mempunyai makna ganda, serta bahasa sesuai dengan tingkat perkembangan anak SMP. SMART Book dikatakan Valid jika skor rata-rata penilaian mencapai 4 dari skor maksimal 5 . Rincian skor penilaian ahli disajikan dari Tabel 3.

Tabel 3. Hasil penilaian ahli terhadap kevalidan SMART Book

\begin{tabular}{lc}
\hline \multicolumn{1}{c}{ Validator } & Skor \\
\hline Ahli Materi & 4.09 \\
Ahli Media & 4.03 \\
Ahli bahasa & 4.50 \\
Skor rata-rata & 4.207 \\
\hline
\end{tabular}

Dari hasil penilaian ketiga ahli tersebut diperoleh hasil bahwa SMART Book yang dikembangkan memenuhi kriteria kevalidan dengan beberapa saran dari ahli materi dan ahli media untuk perbaikan SMART Book sebelum diujicobakan ke Siswa SMP. Saran dari ahli materi antara lain adalah (1) dalam SMART Book, harus dibuatkan jawaban dari setiap soal yang diberikan tanpa mencantumkan caranya; (2) contoh soal dan soal harus diperbanyak lagi; (3) kesalahan dalam penulisan istilah dan simbol harap diperbaiki; (4) glosarium harus diperbanyak lagi dengan memperhatikan istilah-istilah yang ada di geometri.
Sedangkan dari ahli media lebih memberikan saran tentang (1) letak aturan SMART Book disesuaikan dengan ketentuan ISO (International Organization for Standardization); (2) warna bada gambar-gambar bangun lebih dikontraskan agar keterangan pada gambar lebih terlihat; (3) lebih diperbanyak lagi gambar-gambar yang membuat siswa tertarik mempelajari dan memehami materi geometri ini. Sedangkan dari ahli bahasa tidak ada saran.

Hasil revisi dari para ahli tersebut selajutnya diujicobakan kepada 15 siswa SMP Tarbiyyatus Shibyan Tajinan Malang. Hasil uji coba I menunjukkan bahwa SMART Book materi geometri sudah sesuai untuk diterapkan dalam pembelajaran di kelas. Hal ini ditunjukkan dengan hasil pengisian angket siswa yang rata mengisikan respon sangat setuju dengan SMART Book ini dan diperoleh skor rata-rata 3.47 untuk skala penilaian dari 1 sampai dengan 4.dari angket yang sudah diisi oleh siswa didapatkan beberapa saran antara lain yaitu (1) soal latihan kurang lengkap, lebih ditambah lagi; (2) gambar-gambar lebih ditambahin lagi agar siswa lebih tertarik. Beberapa hasil perbaikan dengan menambahkan gambar-gambar adalah pada bagian "mari membaca" dan penambahan soal-soal pada bagian "mari mencoba" 


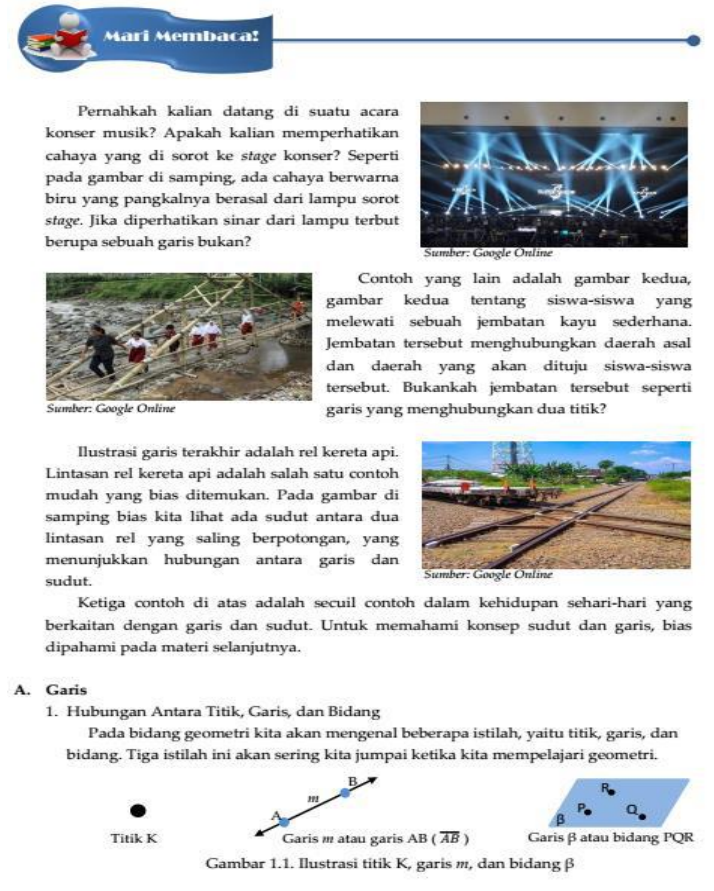

Gambar 2. Kutipan bagian "mari membaca"

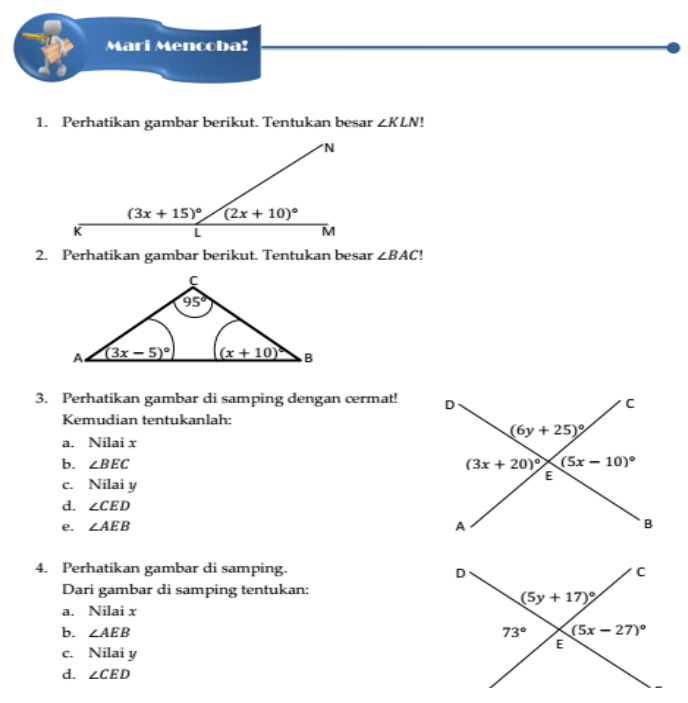

Gambar 3. Kutipan bagian "mari mencoba"

\section{Assesment Phase}

Pada tahap assesment phase ini, Setelah SMART Book direvisi dari hasil validasi dan penyebaran angket untuk subyek uji coba maka SMART Book sudah siap untuk diterapkan di kelas.
Penerapan SMART Book di kelas melibatkan siswa yang sudah menempuh materi Geometri. Penerapan SMART Book ini dilakukan secara berkelompok sehigga dapat memungkinkan siswa berdiskusi dalam memecahkan masalah yang terdapat di SMART Book materi geometri ini.

Setelah itu, dilakukan uji coba ke II ini dengan membiarkan siswa memahami dan mempelajari lagi SMART Book yang sudah direvisi dan setelah itu peneliti memberikan soal dan mewawancari subjek untuk mengetahui respon subjek terhadap SMART Book yang baru. Pada tahap ini peneliti ingin mengetahui apakah SMART Book sudah efektif atau belum jika digunakan dalam pembelajaran. Dari hasil uji coba ini diperoleh hasil nilai rata-rata siswa setelah menggunakan SMART Book ini adalah 80.05 yang sudah memenuhi kriteria sangan baik dari standar kelulusan minimum yang ditentukan oleh sekolah adalah 75 untuk mata pelajaran matematika dengan persentasenya adalah $84,05 \%$ siswa yang mendapatkan nilai di atas KKM yang telah ditentukan oleh pihak sekolah.

Dari hasil uji coba SMART Book ini temuan yang menarik antara lain yaitu (1) selama pembelajaran interaksi antara guru dengan siswa dan siswa dengan siswa terjalin sangat baik karena dalam SMART Book ini, siswa yang dituntut aktif dalam pembelajaran hal ini sesuai dengan pendapat Munawarah (2017) yang menyatakan bahwa dengan diberikannya perangkat pembelajaran (dalam hal ini adalah Buku siwa) akan mempengaruhi keberhasilan dalam proses pembelajaran di kelas dan memberikan kemudahan bagi guru dan siswa dalam melaksanakan kegiatan belajar mengajar ; (2) dengan menggunakan SMART Book materi 
geometri berbasis konstruktivisme ini memudahkan siswa dalam menemukan sendiri pengetahuannya dan mengkaitnya terhadapa pengetahuan yang telah merela miliki sebelumnya dan hal ini didukung dengan hasil penelitia Putri \& Setyaningrum (2017) yang menyatakan bahwa dengan menggunakan pendekatan konstruktivisme, pembelajaran berpusat pada siswa, maka siswa aktif dalam kegiatan pembelajaran, serta siswa mendapatkan pengalamannya sendiri dalam belajar sehingga akan lebih merasuk dalam benak siswa.

Temuan yang selanjutnya adalah (3) dalam uji coba SMART Book ini siswa dibentuk dalam kelompokkelompok kecil, disini siswa saling bekerjasama dan berdiskusi memecahkan soal-soal olimpiade yang terdapat dalam SMART Book. Sholihah dan Mahmudi (2015) menyatakan bahwa proses interaksi dalam diskusi kelompok meningkatkan pemahaman dan pengusaan konsep, karena siswa dapat berbagi pengalaman dan ide dengan teman satu kelompoknya. Lebih lanjut Wismath \& Orr (2015) megungkapkan bahwa dengan berdiskusi siswa mampu menemukan jalan lain dalam memecahkan masalah. Temuan yang terakhir adalah kesalahan dalam mencantumkan satuan dalam pengoperasian matematika, karena seharusnya satuan itu dicantumkan pada saat siswa telah memperoleh kesimpulan.

SMART book ini mengusung pendekatan konstruktivisme dalam penyusunannya, yang mana dalam SMART Book ini siswa hanya diberikan contoh-contohnya terlebih dahulu setelah itu ketika siswa melihat alur dari contohnya maka peserta bisa mengkonstruk pemahamannya sendiri dan memperoleh pengetahuan yang akan mereka pelajari pada setiap babnya. Sehingga guru tidak perlu mengambil alih semua proses dalam pembelajaran di kelas, siswalah yang harus lebih aktif dalam membangun pengetahuannya.

\section{KESIMPULAN DAN SARAN}

Berdasarkan hasil penelitian dan pembahasan maka dapat diambil kesimpulan bahwa pengembangan SMART Book materi Geometri untuk siswa SMP berbasis konstruktivisme adalah Valid, Praktis dan Efektif.

Adapun saran yang bisa diberikan berdasarkan hasil penelitian ini adalah (1) hasil pengembangan berupa SMART Book ini diharapkan dapat digunakan sebagai buku pendamping alternatif dalam proses belajar mengajar di kelas; (2) hasil pengembangan berupa SMART Book ini diharapkan dapat digunakan sebagai salah satu contoh dalam pengembang buku ajar pada materi selanjutnya selain materi geometri ini; (3) SMART Book ini hanya terbatas pada materi Geometri untuk tingkat SMP saja diharapkan kedepannya untuk peneli berikutnya bisa dikembangkan untuk materi Geometri SMA juga atau untuk materi yang lain. (4) bagi penelitian selanjutnya dapat dilakukan untuk mengetahui bagaimana peningkatan kemampuan pemecahan masalah siswa dengan menerapkan SMART Book ini melalui Penelitian Tindakan Kelas.

\section{DAFTAR PUSTAKA}

Khotimah, K., dkk. (2012). Pengembangan Bahan Ajar Matematika Mengacu pada Pembelajaran Berbasis Masalah bagi Siswa Kelas VIII Sekolah Menengah Pertama Negeri Rimbang Kuang. JPM: Jurnal 
DOI: https://doi.org/10.24127/ajpm.v8i2.2156

Pendidikan Matematika 6(1), 19-34

Marlina, M. (2013). Pengembangan Perangkat Pembelajaran Geometri SMP dengan Strategi Pembelajaran Kolaboratif. PYTHAGORAS: Jurnal Pendidikan Matematika 8(2), 146-159

Muhassanah, N., dkk. (2014). Analisis Ketrampilan Geometri Siswa dalam Memecahkan Masalah Geometri Berdasarkan Tingkat Berfikir Van Hiele. Jurnal Elektronik Pembelajaran Matematika 2(1), 54-66

Munawarah. (2017). Pengembangan Perangkat Pembelajaran Matematika dengan Menggunakan Pendekatan Kontekstual. MaPan: Jurnal Matematika dan Pembelajaran 2(2), 168-186

Nopriana, T. (2015). Disposisi Matematika Siswa Melalui Model Pembelajaran Geometri Van Hiele. FIBONACCI: Jurnal Pendidikan Matematika dan Matematika 1(2), 80-94

Nurhidayati, E. (2017). Pedagogi Konstruktivisme dalam Praksis Pendidikan Indonesia. Indonesia Journal of Educational Counseling 1(1), 1-14

Plomp, T. (2010). Educational Design Research: an Introduction (Plomp, $T$ \& Nieveen, Ed.) Netherlands Institute for Curriculum Development.

Putri, N. A., \& Setyaningrum, W. (2017).

Keefektifan Pembelajaran Matematika pada Materi Segiempat Menggunakan Pendekatan Konstruktivisme Ditinjau dari Kemandirian Belajar Siswa dan Prestasi Belajar Siswa Kelas VII SMP
Negeri 1 Manisrenggo. Jurnal Pendidikan Matematika 6(7), 84-95

Rangkuti, A.N. (2014). Konstruktivisme dan Pembelajaran Matematika. Jurnal Darul Ilmi 2(2), 61-76

Safrina, K., dkk. (2014). Peningkatan Kemampuan Pemecahan Masalah Geometri Melalui Pembelajaran Kooperatif Berbasis Teori Van Hiele. Jurnal Didaktik Matematika l(1), 9-20

Setiyawan, H. (2016). Pengembangan Bahan Ajar Matematika Bab Integral Berbasis Konstruktivisme pada Kelas XII IPA. Jurnal INOVASI 18(2), 3140

Sholihah, D. A. \& Mahmudi, A. (2015) Keefektifan Experiential Learning Pembelajaran Matematika MTs Materi Bangun Ruang sisi Datar. Jurnal Riset Pendidikan Matematika 2(2), 175-185

Wismath, S. L., \& Orr, D. (2015). Collaborative Learning in Problem Solving: A Case Study in Metacognitive Learning. The Canada Journal for the Scholarship of Teaching and Learning 6(3), 1-11. http://dx.doi.org/10.5206/cjsotl.r cacea.2015.3.10 